\title{
22. COMMISSION DES METEORES ET METEORITES
}

President: P.M. Millman.

SeCRETARY: A.F. Cook.

\section{First Session, Thursday, 24 August 1967, 10:30 hours}

The business meeting of Commission 22 was called to order by P.M. Millman, who was in the chair. Approximately 50 members and guests were present. The Chairman noted with regret the loss by death of one of the members of the Commission, Monsieur F. Baldet from France.

There was general discussion of the Draft Report, and it was noted that a number of 1964-1966 references had been omitted. Since only corrections of errors in the text of the Draft Report were allowed by the Executive Committee, it was agreed that a supplementary list of 1964-1966 references, including titles, should be appended to these proceedings. The Chairman pointed out the duty of all members of the Commission to supply to the President complete lists of references from their respective countries.

The appointments by the Executive Committee of $\mathrm{Z}$. Ceplecha as the new President of Commission 22 and of R. E. McCrosky as the new Vice-President, were announced. New members of the Commission, approved by the Executive Committee, were noted as follows:

Members: E. Anders, J. Davis, W. G. Elford, C. Ellyett, C. S. L. Keay, T. R. Kaiser, M. Kresáková, B. A. McIntosh, T.N. Nazarova, H. Oleak, Z. Plavcová, J. Rajchl, R. B. Southworth, I.F. Verniani.

The following have been asked to serve for the coming term as consulting members:

Consulting Members: W. M. Alexander, E.P. Henderson, M. H. Hey, B. H. Mason, U. B. Marvin, K. I. Sztroky, F. Wickman, J. Zähringer.

It was agreed that the current Organizing Committee of the Commission, together with the President, Vice-President and Vice-President Elect, should act as a Nominating Committee to select a slate of five members to be nominated as the Organizing Committee to serve during the 1967-1970 term.

C.L. Hemenway announced that a new international panel under the auspices of COSPAR had been formed to attempt to resolve some of the confusion that exists in the observational data on interplanetary dust, obtained by observations from rockets and satellites, and from collection techniques on the earth's surface.

\section{Second Session, Friday, 25 August 1967, 10:30 hours}

The Nominating Committee presented the following slate for the 1967-70 term.

Organizing Committee: P.B. Babadžanov, W.G. Elford, C. L. Hemenway, P.M. Millman, A. A. Yavnel.

Meteorite Committee: Chairman: A. A. Yavnel. Vice-Chairman: E. Anders.

There were no further nominations and the above slate was elected unanimously.

The items appearing on pages cviii-cix of the I.A.U. Agenda were now taken up.

Item 1-It was unanimously agreed that the Executive of Commission 22 produce an up-to-date mailing list of astronomers active in research in meteoric astronomy. Z. Ceplecha undertook to have this revised each year and mailed to all on the list.

Item 2-L. Kresák noted that arrangements had been made for the early publication (6 to 8 months) of the proceedings of I.A.U. Symposium No. 33, the Physics and Dynamics of Meteors.

Item 3-Members of the Commission were urged to circulate freely their published papers, making use of the mailing list mentioned under Item 1.

Item 4-The policy of the Executive Committee of the I.A.U., that funds to assist young astronomers in attending General Assemblies and Symposia should not be cut, was duly noted and approval for this policy expressed. 
Item 5-It was agreed unanimously that the current name of Commission 22 remains suitable and should not be changed at the present time.

Item 6-Note was taken of the importance of recording bright fireballs, particularly in connection with the falls of meteorites.

Item 7-This item was withdrawn by the originator.

Item 8-No new suggestions for further symposia or colloquia were made at this time. All those interested in meteorite research were requested to send comments to Dr. G. Harbottle, International Atomic Energy Agency, Vienna, re possible subjects for inclusion in the program of the international meteorite symposium to be held in Vienna, August 7-13, 1968.

In view of the IAU Symposium No. 33, to be held at Tatranská Lomnica, September 4-9, 1967, no papers were presented at the Commission 22 sessions in Prague.

\section{SUPPLEMENTARY LIST OF 1964-1966 REFERENCES}

Astapovič, I.S., Terentjeva, A.K. 1966, The Leonid Meteor Shower, Komety Meteory, 14, 24.

Astavin-Razumin, D.L. 1966, A Method for Determining the Stellar Magnitudes of Meteors, Meteornaja materija $v$ atmosfere Zemli, Nauka, Moscow, 93.

Bronšten, V.A. 1966, Theory of the Spectroscopic Investigation of Meteorite-Dropping Bolides, Meteoritika, 27, 97.

Bronšten, V.A., Liubarsky, K.A. 1966, Radiation from Meteors and Bolides, Meteornaja materija v atmosfere Zemli, Nauka, Moscow, 3.

Chebotarev, R.P. $\quad 1966$, On Simple Measurements of the Range of Meteors, Bjull. Inst. Astrofiz. DušanbeStalinabad, no. 47, 3.

Cvetkov, V.I., Bojarkina, A.P. 1966, Results of the Investigation of New Evidence on the Fall of the Tunguska Meteorite in 1908, Meteornaja materija v atmosfere Zemli, Nauka, Moscow, 81.

Delov, I.A. 1966, Equipment and Methods of Investigation of Irregular Movements in the Meteor Zone, Resultaty issledovanij po MGP, issl. meteorov, no. 1, 133.

Delov, I.A. 1966, Turbulent Motions in the Atmosphere at Heights of 90-110 km and their Connection with other Phenomena, Meteory, Kiev Univ., 126.

Doğan, N. 1966, On the Diurnal and Seasonal Variations in the Number of Micrometeoritic Particles, and their Origin, Commun. Fac. Sci. Ankara Univ., 15A, 25.

Fesenkov, V.G. 1964, On the Orbit of the Tunguska Meteorite, Meteoritika, 25, 163.

Fialko, E.I. $\quad 1966$, On the Evaluation of the De-ionization Rate in Meteor Trails, Komety Meteory, 13, 22.

Fialko, E.I. 1966, Rates of Meteor Echoes on $\lambda=10 \mathrm{~m}$ During the IGY-IGC Period, Komety Meteory, 13,41 .

Fialko, E.I. 1966, On the Comparison of Meteor Radars According to their Sensitivity, Komety Meteory, $14,38$.

Fialko, E.I., Chumak, Iu.V. 1966, On the Use of Intermediate Type Echoes for the Measurement of the Diffusion Coefficient and Electron Line Density, Komety Meteory, 14, 16.

Fialko, E.I., Moisya, R.I., Kolomiets, G.I., Melnik, V.I., Chumak, Iu.V. 1966, The Experimental Study of the Energy Distribution of Meteor Bodies, Meteory, Kiev Univ., 144.

Fialko, E.I., Moisya, R.I., Melnik, V.I., Kolomiets, G.I. 1966, Radar Observations of Geminids in 1964, Komety Meteory, 14, 19.

Glöde, P. 1966, Results of Radar Meteor Observations of the Quadrantid Shower, Kleinheubacher Berichte, 11, 157.

Ivanov, K.G. 1966, Reply to an Article by A.V. Zolotov Entitled 'Thermal Ionization of the Ionosphere by the Shock Wave of the Tunguska Explosion of 1908', Geomagn. Aeronom., 6, 777.

Kaščev, B.L., Nečitailenko, V.A., Suverov, Iu.I. 1966, The Drift of Trains, Meteory, Kiev Univ., 119. Katasev, L.A. 1966, Issledovanije meteorov v atmosfere Zemli fotograficheskim metodom, Leningrad.

Kirova, O.A., Zaslavskaja, N.I. 1966, Some Results on the Dispersion of Material from the Fall Area of the Tunguska Meteorite, Meteoritika, 27, 119.

Kovšun, I.N. $\quad 1966$, On the Number of Particles of Fragmenting Meteors, Meteory, Kiev Univ., 54.

Kovsun, I. N. 1966, On the Density of Meteor Bodies, Meteory, Kiev Univ., 63.

Kramer, E.N. 1966, The Orbit, Luminosity and Spectrum of the Bright Meteor of 5 July, 1962, Meteory Kiev Univ., 75.

Kručinenko, V.G. 1966, On the Drag of Meteor Bodies, Meteory, Kiev Univ., 47. 
LaPaz, L. 1965, Catalog of the Collections of The Institute of Meteoritics, The University of New Mexico, Univ. New Mexico Pub. in Meteoritics, no. 4, Univ. New Mexico Press, Albuquerque.

Liubarsky, K.A. 1966, Variations in Telescopic Meteor Heights, Resultaty issledovanij po MGP, issl. meteorov, no. $1,160$.

Liubarsky, K.A. 1966, More on the Determination of the Luminosity Function of Meteors, Meteornaja materija v atmosfere Zemli, Nauka, Moscow, 97.

Liubarsky, K.A., Cvetkov, V.I. $\quad$ 1966, Luminosity Function of Meteors Observed 1962-1963, Meteornaja materija v atmosfere Zemli, Nauka, Moscow, 103.

Martynenko, V.V. 1966, Amateur Meteor Astronomy in the Crimea, Meteory, Kiev Univ., 147.

Nekrasov, V.I., Emelianov, Iu. M. 1966, Pre-fall Characteristics of the Forest in the Area of the Tunguska Meteorite, Meteoritika, 27, 128.

Nemirova, E.K. 1966, Results of Observations of the Polarization Effect for Sporadic Meteors, Komety Meteory, 13, 29.

Pokrovsky, G.I. 1966, On the Explosion of Meteor Bodies Moving in the Atmosphere, Meteoritika, 27, 103.

Romig, M., Lamar, D. 1966, Anomalous Sounds and Electromagnetic Phenomena Associated with the Flight of Bolides, Meteornaja materija v atmosfere Zemli, Nauka, Moscow, 38.

Rubcov, L.N. 1966, On the Limiting Magnitude of Meteors Registered at a Wavelength of $17 \mathrm{~m}$, Bjull. Inst. Astrofiz. Dušanbe-Stalinabad, no. 45, 12.

Sidorova, V.V. (editor) 1966, Radio-wave Propagation by Meteors, Parts 3-4, Kazan Univ., Kazan.

Smirnov, V.A. 1966, On Methods of Obtaining and Studying Spectrograms of Meteors, Meteory, Kiev Univ., 90.

Smirnov, V.A. 1966, On Radiation and Methods of the Spectrophotometry of Meteors, Meteory, Kiev Univ., 104.

Sodiev, U. 1966, Investigation of the Train of an Orionid Meteor Observed on the 22nd of October, 1962, Resultaty issledovanij po MGP, issl. meteorov, no. 1, 156.

Terentjeva, A.K. 1966, A Possible Meteor Stream of the Family from Pons-Winnecke Periodic Comet, Meteory, Kiev Univ., 40.

Vinogradov, A.P., Devertz, A.L., Dobrina, E.I. 1966, Concentration of $\mathrm{C}^{14}$ in the Atmosphere at the Time of the Tunguska Fall, and a Discussion of Antimatter, Dokl. Akad. Nauk SSSR, 168, 900.

Watkins, C.D. 1966, High Sensitivity Radar Investigations of Magnetic Field-Aligned Ionization in the E Region, Electron Density Profiles in Ionosphere and Exosphere, edited by E. V. Frihagen, North Holland Publ. Co., 208.

Watkins, C.D., Sutcliffe, H.K. 1965, Radar Observations of Weak Field-Aligned Ionization at a Frequency of $300 \mathrm{Mc} / \mathrm{s}$, J. atmos. terr. Phys. 27, 309.

Zotkin, I.T. 1966, The Trajectory and Orbit of the Tunguska Meteorite, Meteoritika, 27, 109.

Zotkin, I.T. 1966, A Bolide over the Urals, Meteornaja materija v atmosfere Zemli, Nauka, Moscow, 69. 